\title{
ESLab application to a boreal watershed in southern Finland: preparing for a virtual research environment of ecosystem services
}

\author{
Maria Holmberg • Anu Akujärvi • Saku Anttila • Lauri Arvola • Irina Bergström • \\ Kristin Böttcher $\cdot$ Xiaoming Feng $\cdot$ Martin Forsius $\cdot$ Inese Huttunen • \\ Markus Huttunen · Yki Laine · Heikki Lehtonen · Jari Liski - Laura Mononen • \\ Katri Rankinen • Anna Repo • Vanamo Piirainen • Pekka Vanhala • \\ Petteri Vihervaara
}

Received: 30 April 2014/Accepted: 11 November 2014/Published online: 22 November 2014

(C) Springer Science+Business Media Dordrecht 2014

\begin{abstract}
We report on preparatory work to develop a virtual laboratory for ecosystem services, ESLab, and demonstrate its pilot application in southern Finland. The themes included in the pilot are related to biodiversity conservation, climate mitigation and eutrophication mitigation. ESLab is a research environment for ecosystem services (ES), which considers ES indicators at different landscape scales: habitats, catchments and municipalities and shares the results by a service that utilizes machine readable interfaces. The study area of the pilot application is situated in the boreal region of southern Finland and covers 14 municipalities and ten catchments including forested,
\end{abstract}

Electronic supplementary material The online version of this article (doi:10.1007/s10980-014-0122-z) contains supplementary material, which is available to authorized users.

M. Holmberg ( ( ) A. Akujärvi · I. Bergström ·

M. Forsius · J. Liski · L. Mononen - K. Rankinen ·

A. Repo $\cdot$ P. Vanhala $\cdot$ P. Vihervaara

Natural Environment Centre, Finnish Environment

Institute, P.O. Box 140, Mechelininkatu 34 a,

00251 Helsinki, Finland

e-mail: maria.holmberg@ymparisto.fi

S. Anttila $\cdot$ K. Böttcher · Y. Laine

Data and Information Centre, Finnish Environment

Institute, P.O. Box 140, Mechelininkatu 34 a,

00251 Helsinki, Finland

L. Arvola

Lammi Biological Station, Helsinki University,

Pääjärventie 320, 16900 Lammi, Finland agricultural and nature conservation areas. We present case studies including: present carbon budgets of natural ecosystems; future carbon budgets with and without the removal of harvest residues for bioenergy production; and total phosphorus and nitrogen future loads under climate and agricultural yield and price scenarios. The ESLab allows researchers to present and share the results as visual maps, statistics and graphs. Our further aim is to provide a toolbox of easily accessible virtual services for ES researchers, to illustrate the comprehensive societal consequences of multiple decisions (e.g. concerning land use, fertilisation or harvesting) in a changing environment (climate, deposition).

Keywords Biodiversity · Eutrophication · GIS . Forestry $\cdot$ Agriculture $\cdot$ Carbon budget

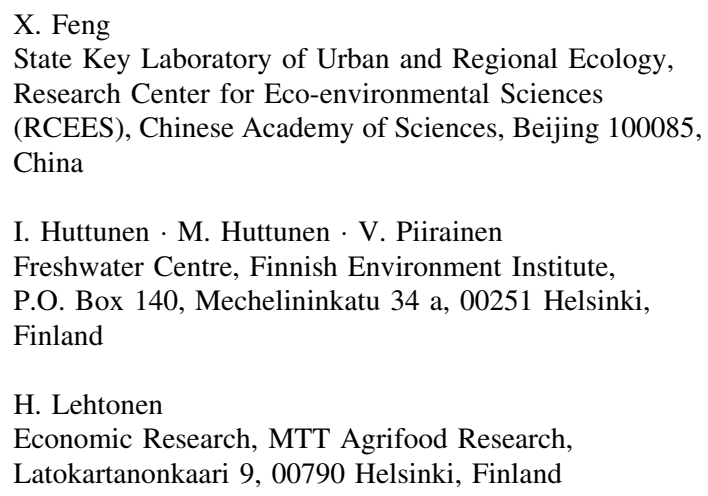

I. Huttunen · M. Huttunen · V. Piirainen

Freshwater Centre, Finnish Environment Institute, P.O. Box 140, Mechelininkatu 34 a, 00251 Helsinki, Finland

H. Lehtonen

Economic Research, MTT Agrifood Research, Latokartanonkaari 9, 00790 Helsinki, Finland 


\section{Introduction}

Ecosystem services (ES) are the contributions that ecosystems make to human well-being. The value of nature for humans has been studied at least since the 1960s when Coase discussed the consequences of assigning rights to pollute versus rights to clean air (Kolstad 2000). Human activities that cause global change contribute to changes in biodiversity with subsequent harmful effects on ecosystem processes and ES (Chapin III et al. 2000; Barnosky et al. 2012). Biodiversity is the crucial force underpinning the delivery of ES (Mooney et al. 2009; Cardinale et al. 2012). Despite international commitment to the convention on biological diversity (CBD 2010), the rate of biodiversity loss does not appear to be slowing (Butchart et al. 2010). Since the Millennium Assessment (MA 2005) there has been a surge of publications on studies on ES and the numbers of articles published on the topic "ecosystem services", as well as the numbers of citations to the articles, have been increasing steadily for the last decades (Vihervaara et al. 2010). While the concept of ES has great potential of bridging the gap between conservation aims and adopted policies, uncritical application of the concept also entails problems and risks (Ridder 2008; Redford and Adams 2009; Jax et al. 2013). There are, however, documented advantages of the method and reasons to apply it in the hope of attaining better levels of conservation and links between biodiversity and ES issues (Cardinale et al. 2012; Maes et al. 2012).

The concept of essential biodiversity variables aims to cover a comprehensive bundle of biodiversity indicators that fulfil the criteria of scalability, temporal sensitivity, feasibility, and relevance (Pereira et al. 2013). They can be based on monitoring methods such as remote sensing, local sampling schemes, and for instance citizen science. These biodiversity indicators form the basis to analyse trade-offs between different ES. The complex multi-layered relationships between ES and biodiversity provide challenges both for multidisciplinary science and policy (Mace et al. 2012). A key scientific question is the development of dynamic models of ES coupled to biogeochemical cycles for scenario analysis in a changing environment. In policy, the management of multiple ES is a crucial challenge (Fu et al. 2013).

Several approaches have been applied to classify ES. In the Common International Classification of
Ecosystem Services (CICES), services are classified into provisioning services, regulating and maintenance services, and cultural services (Potschin and Haines-Young 2011). In this classification, regulating and maintenance services cover all the ways in which living organisms can mediate or moderate the ambient environment that affects human performance, such as carbon sequestration, water purification, nitrogen retention, pollination and biodiversity. Regulating services are those that arise as the result of the functioning of physical and biogeochemical processes in nature, forming the biogeochemical cycles of key elements such as carbon $(\mathrm{C})$, nitrogen $(\mathrm{N})$, phosphorus $(\mathrm{P})$ and other nutrients and trace elements. These processes are dynamic and the rates at which they unfold are determined on one hand by the characteristics of the spatial location where they operate, such as bedrock, topography, altitude and geographic latitude, and on the other hand by the temporal drivers such as changes in climate, deposition, population and economic pressure, land use and management practices. The interaction of these processes result in the variable state of the ecosystem that for a certain moment in time can be observed as stocks or fluxes of, e.g. carbon and nitrogen. A momentary observation of a certain variable reflects the history of the temporal drivers. Dynamic process models as well as statistical models can be utilized to study time series of observations of ecosystem variables, while process based models are in most cases preferred for studying the impact of future changes in the temporal drivers, i.e. scenario analysis. Other quantitative methods to assess ES include element mass balance calculations to quantify retention processes. Crossman et al. (2013) call for new integrated assessment models that include biophysical and socio-economic drivers of land use change and ES supply and demand impacts. Dick et al. (2014) recommend using data on different scales and Potschin and Haines-Young (2013) emphasize the strengths of a place-based approach. Qualitative and quantitative assessment methods have been combined by Kopperoinen et al. (2014) in a new method to consider ES in land use planning. Bagstad et al. (2013a) present an approach to quantify the flow of services between ecosystems and their beneficiaries. Several policy processes drive and motivate the development of an integrated modelling framework on ES. Current legislation, directives and strategies such as the habitats directive (EC 1992), the water 
framework directive (EC 2000) and the EU biodiversity strategy (EC 2011a) involve national reporting on the status and change in natural habitats. Implementation may lead to situations in which the criteria lead to conflicting interests, or trade-offs. Integrated modelling frameworks provide the opportunity to study the conditions under which trade-offs occur in a changing environment.

ES models often involve exchanging and analysing of geospatial data (Feng et al. 2011). Traditionally programs to run these models are installed in standalone or closed network systems. Thus, retrieving the required data for the models, and more importantly sharing the results, is often slow. Furthermore, users of individual ecosystem models often need to have detailed technical knowledge of the models and therefore widespread utilization of models is rare in the research community. Geographic information systems (GIS) currently strongly evolve towards internet based services regarding data, processing (calculation) and user applications. These services are based on the standardized and open interfaces that share the data, metadata and calculation processes online in a machine-readable format (see e.g. http:// www.opengeospatial.org/standards). Such methods, following the principles of open and scalable data, are also recommended for the research infrastructure development of environmental applications (Hardisty et al. 2013; Dick et al. 2014). Bagstad et al. (2013b) reviewed a variety of available tools for the quantification of ES and found that many tools are not ready to be used for widespread decision making. One of their recommendations was that the data needed for the ES models should be better organized and more easily accessible. Ultimately, openly available information on ES indicators and values may increase transparency in local and national decision making. Applying the concept of ES to promote informed decision making is an activity involving multiple disciplines, meeting challenges such as those identified by Pooley et al. (2014): "methodological challenges, value judgments, theories of knowledge, disciplinary prejudices, and interdisciplinary communication". Their suggested ingredients for a successful multiple disciplinary project include explaining methods, developing a shared language, and facilitating on-going communications (Pooley et al. 2014).

Future provision of ES depends on the temporal development of the factors driving the changes in crucial ecosystem processes. Key drivers of change in Finland are climate warming as well as societal response in the form of forest and agriculture management strategies directed towards mitigation and adaptation options. Global climate change is characterised by warming of the high-latitude areas, which has also been observed in Finland (Tietäväinen et al. 2010). Jylhä et al. (2014) report significant trends of increases in annual and spring mean temperature of $0.4{ }^{\circ} \mathrm{C}$ per decade, thinning of annual mean snow depth and a shortening of the lake-ice season by 17 days per decade for a region in southern Finland. Forsius et al. (2013) analysed the impacts of climate change on several key ES in Finland.

In an effort to mitigate global climate change, bioenergy is one of the alternative fuel sources that has been vigorously promoted in the European Union (Bentsen and Felby 2012), although trade-offs between bioenergy carbon sinks have been identified (Böttcher et al. 2012). Conservation of biodiversity in the face of an increasing use of bioenergy is also recognized as a challenge (Kraxner et al. 2013). Forest harvest residues are an important source of bioenergy in Finland. The residual biomass includes branches, stumps, roots and other tree parts that are cut in harvesting but are not used in the forest industry. The recovered residues are often used in district heating plants in substitute of fossil fuels or peat. This practice has two kinds of effects on the carbon dioxide emissions of district heating: it helps to avoid the emissions from other fuels, but it weakens carbon sequestration in forest. The reason is that the harvest residues would store carbon for a long time if left in forest to decompose, while, if they are combusted, carbon is released to the atmosphere at once. The overall effect of using the harvest residues for the production district heating depends on the balance between these two effects (Zanchi et al. 2012; Repo et al. 2014).

While climate warming may improve crop production potential in northern latitudes, pest pressure and continuous changes in the regional and global market may present significant challenges for farmers and agricultural production in Nordic countries (Hakala et al. 2011). Rötter et al. (2013) estimated the future yield of Finnish cereal crops for the 21st century, suggesting that the yield potential of Finnish major crops under future climate change will most likely sustain the current level, or decrease in some extreme 
scenarios. Thus, Nordic farmers are facing the challenge of how to narrow the gap between potential and actual yield. Crop yields may increase in most optimistic conditions if both crop yields and market prices of agricultural products increase significantly. Significant and permanent decline in crop yields is, however, expected if little adaptation realises due to discouraging prices and policies (Lehtonen et al. 2014). Increased nutrient loading to surface waters is also projected as a combination of changes in arable land use patterns and climate (Forsius et al. 2013).

Deposition of air-borne nitrogen $(\mathrm{N})$ is another important driver of long-term changes in the ecosystem processes, contributing to the eutrophication of ecosystems and nutrient release. The role of $\mathrm{N}$ in acidification has been minor compared to that of sulphur ( $\mathrm{S}$ ) but this is changing because $\mathrm{S}$ deposition has decreased much more than $\mathrm{N}$ deposition. Despite the general decrease in air pollutants, recent increase in $\mathrm{N}$ deposition has been reported (Ruoho-Airola et al. 2014). Although the relative importance of $\mathrm{N}$ deposition is often masked by climate warming and land use change in high-latitude areas such as Finland, N deposition impacts can be identified (Dirnböck et al. 2014).

We report on preparatory work to develop a virtual laboratory for ecosystem services ESLab and demonstrate its pilot application in southern Finland. Our long term objective is to develop a web based research environment (ESLab) to assess and valuate ES on-line, using dynamic process oriented as well as statistical models combined with indicators and spatially explicit data. The development of ESLab includes effective multidisciplinary collaboration between ES researchers and technical specialists. The open web tool will include extensive documentation on the methods and data used. Its pre-calculated case studies will demonstrate the consequences of different assumptions and thereby it has the potential to facilitate communication between experts in different fields (e.g. political sciences, ecology, hydrology, biology, limnology, geography, systems analysis and modelling). ESLab will also facilitate sharing data and information, thereby promoting transparency and openness.

In this pilot phase we have compiled a first set of methods and available models and indicators, and applied them to a research area in southern Finland. Through a series of applications this paper illustrates a range of methods available for ES assessment in
Finland, and gives examples of the kinds of data used in the calculations.

\section{Methods}

ESLab virtual research environment

ESLab was developed as a modelling framework for assessing ES. The main themes of the pilot ESLab application are related to biodiversity conservation, mitigation of climate change and mitigation of eutrophication (Fig. 1). ESLab is implemented as a virtual research environment that aims to share ES information, its interpretations and related models within the research community. The concept relies on the standard and open data, metadata and processing services created for the ecosystem information (Fig. 2). The pilot version of ESLab is designed for exploring, evaluation and sharing results from the ES assessments. It thus provides a common platform for the quantification of key ES and spatial integration of assessment results. The pilot version of ESLab was built with the web-based mapping software (Geocortex by Latitude Geographics Group Ltd.) using available infrastructure utilities of the Finnish Environment Institute. It utilizes geospatial data interfaces created from the ES assessments and relevant background data (including land cover, topography, municipalities, lakes and rivers). Geospatial data services for these data sets were created with the ArcGIS server (by Environmental Systems Research Institute, Inc., Esri). The pilot version of ESLab includes pre-calculated model results and statistics at different spatial scales. The results may be aggregated at different levels: catchments, municipalities and land use units. The different spatial scales are needed because different processes and decisions are relevant at different spatial scales, e.g. decisions on collecting harvest residues are made at the municipal scale, while water management decisions are made at the scale of catchments or watershed basins. The scenarios explored in the pilot are sector specific: concerning the removal of harvest residues in forestry; and prices and yields in agriculture. Only the agricultural scenarios take climate change into account. Assumptions of different levels of $\mathrm{N}$ deposition have not been included in the forestry or the agricultural scenarios. Researchers can inspect, analyse and comment their findings in a browser based 
Fig. 1 ESLab components: themes, methods, drivers and scales. The dashed line indicates work in progress in implementing the biodiversity indicator

\begin{tabular}{|c|c|c|c|c|}
\hline $\begin{array}{l}\text { Theme } \\
\text { Process } \\
\text { Variable }\end{array}$ & Method & Driver & Spatial scale & Time frame \\
\hline $\begin{array}{l}\text { Biodiversity } \\
\text { Habitat suitability } \\
\text { Bird species }\end{array}$ & Indicator & Forest characteristics & Grid & Present \\
\hline $\begin{array}{l}\text { Climate change } \\
\mathrm{C} \text { sequestration } \\
\mathrm{CO}_{2} \text { emissions }\end{array}$ & $\begin{array}{l}\text { Yasso07 } \\
\text { LUONNIKAS }\end{array}$ & $\begin{array}{l}\text { C in litter } \\
\text { Land use }\end{array}$ & $\begin{array}{l}\text { Municipality } \\
\text { Municipality }\end{array}$ & $\begin{array}{l}\text { Present, future } \\
\text { Present }\end{array}$ \\
\hline $\begin{array}{l}\text { Eutrophication } \\
\mathrm{N}, \mathrm{P} \text { retention } \\
\text { Leaching of N, P } \\
\text { Sediment retention } \\
\text { Erosion sensitivity } \\
\text { Vegetation response } \\
\text { Critical load } \\
\text { exceedance }\end{array}$ & $\begin{array}{l}\text { VEMALA } \\
\text { USLE } \\
\text { Empirical critical loads }\end{array}$ & $\begin{array}{l}\begin{array}{l}\text { Climate, agricultural } \\
\text { production }\end{array} \\
\text { Land use } \\
\mathrm{N} \text { deposition }\end{array}$ & $\begin{array}{l}\text { Catchment } \\
\text { Catchment } \\
\text { Grid }\end{array}$ & $\begin{array}{l}\text { Present, future } \\
\text { Present } \\
\text { Present, future }\end{array}$ \\
\hline
\end{tabular}

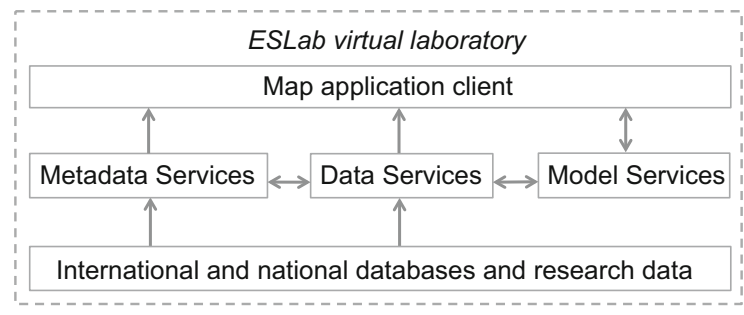

Fig. 2 ESLab services and data flows. The solid lines indicate available infrastructure utilities and the dashed line indicates work in progress in defining the technical system architecture model for ESLab

map application and have the option to add their own or online data sets (e.g. by European Environment Agency, Google Inc. or by various national data provides). ESLab allows researchers to save and share their findings either as a new customized view on the map application or as static maps.

\section{Biodiversity conservation}

Biodiversity can be promoted by allowing for land use and forest structures that contribute to the conservation of suitable habitats. The first biodiversity indicator to be included in ESLab is habitat suitability for various bird species. The implementation of this indicator in ESLab is work in progress, which relies on the results of Vihervaara et al. (this issue). The development of spatially-explicit biodiversity indicators for the forest ecosystems in the study area was based on combining information on forest structural parameters and bird observation data. National Land Survey of Finland (NLS) has provided airborne laser scanning data since 2008 and their open access data now covers most of the area of Finland. Variables such as main tree species, mean height, basal area and biomass were used for spatial analysis with GIS (see Vihervaara et al. 2012, this issue for further details). The bird observation data (41 species) was collected from three data sources: Atlas mapping (FMNH), Bird ringing data $(\mathrm{FMNH})$, and local bird watching organizations (Tiira system) (Appendix 1 Table 1). Data was analysed by comparing distributions of observed and randomly generated data. Buffer zones with $50 \mathrm{~m}$ diameter were created around each bird observation point $(n=2,875)$ and each randomly generated point. Within these buffer zones, the data was reclassified, for example in the case of forest biomass the data was categorized into nine classes. The numbers of pixels were summed for each biomass class, separately for the buffers around the bird observations and the randomized buffers. The pixel distributions were compared in order to identify whether any particular biomass class showed larger relative proportion of pixels in the buffers around the bird observations than in the randomized buffers. The same approach was applied to other forest structure parameters (14 in total) that were derived from the NLS's airborne laser scanning data and plot field measurements by the University of Eastern Finland (Vihervaara et al. this issue).

Climate change mitigation

An important means of climate change mitigation in Finland is provided by ecosystems, especially forests, 
sequestering carbon, while the use of harvest residues to supplement coal in energy production is receiving growing interest as a means of mitigating emissions following fossil fuel consumption. A case study involving all 14 municipalities of the study area demonstrates the capacity of the different land use forms to sequester carbon. Another case study from one of the municipalities in the study area (Hämeenlinna) illustrates the trade-off between using harvest residues for bioenergy and letting the harvest residues decompose slowly in the forest.

To illustrate the present level of carbon sequestration by various land use types for each municipality in the study area, estimates of carbon budgets for forests, cropland, mires and water bodies were calculated using the LUONNIKAS calculation tool (Haaspuro 2013). The tool calculates, for a specific year, the amount of carbon sequestered into the ecosystems as well as the amount of greenhouse gas emissions. Data for the year 2009 were used for calculations. When $\mathrm{CH}_{4}$ or $\mathrm{N}_{2} \mathrm{O}$ emissions were assumed to be significant they were added to the calculations and the results were given as $\mathrm{CO}_{2}$ equivalents. LUONNIKAS is formulated as mass balance expressions using data easily available at the municipal level. The calculation methods for GHG emissions and removals follow the methodology used in the Land Use, Land Use Change and Forestry (LULUCF) sector in Finland's National Inventory of greenhouse gases (Statistics Finland 2013). On the LULUCF sector the emissions and removals are calculated for managed land use types. The sector includes the carbon budgets of forest land, cropland and peat extraction sites. Inland waters and undrained mires are considered unmanaged, and therefore the carbon budgets of those were calculated with the methods based on regionally representative studies mostly from Finland and Sweden.

Using forest harvest residues for bioenergy leads to lower $\mathrm{CO}_{2}$ emissions from energy production but also to a decrease in the $\mathrm{C}$ sink of the forest. The temporal development of the change in $\mathrm{C}$ sink is illustrated for Hämeenlinna with different assumptions concerning future levels of use of bioenergy. The $\mathrm{C}$ retention and budget of forest soil was estimated using Yasso07 model (Tuomi et al. 2011). Yasso07 is a dynamic model of the carbon cycle in soil. It consists of five state variables representing groups of organic compounds in soil (polar-solvent soluble, non-polarsolvent soluble, acid-hydrolysable, Klason lignin and humus). Temperature and precipitation control decomposition. Size is an additional factor controlling the decomposition of woody litter. The parameter values of Yasso07 have been estimated using a Markov chain Monte Carlo method and a worldwide dataset of about 12,000 measurements of decomposition and soil organic carbon. The validity of Yasso07 has been tested in numerous studies in different parts of the world, e.g. Peltoniemi et al. (2004), Palosuo et al. (2005), Böttcher et al. (2008), Ortiz et al. (2013).

As the base for the forest management and use of harvest residue scenarios we used a business-as-usual forest resource scenario that The Finnish Forest Research Institute has estimated for a set of forestry centres and regions in Finland. These regions cover several municipalities. We down-scaled the values to Hämeenlinna by tree species (pine, spruce, broadleaved trees) based on the share of the region's total tree volume found in this municipality. We derived the complete annual carbon cycle of forests based on these scenarios and the Yasso07 soil model using a concept we have developed earlier (Liski et al. 2002, 2006). We simulated two bioenergy scenarios in Hämeenlinna between 2010 and 2040. In the first scenario, the district heating plants stop using any biomass and produce the 2010 amount of energy annually from coal. In the second scenario, the power plants increase their use of biomass from the current level and start using all harvest residues available each year. The rest of the district heating needed to meet the 2010 level is produced from coal. In both scenarios, the development of forests follows a business-as-usual pathway.

\section{Eutrophication mitigation}

Eutrophication of water bodies can be mitigated by reducing the load of nutrients leaving terrestrial areas in agricultural production, as well as by considering the erosion sensitivity of the catchments in planning the location of agricultural crops. The eutrophication of terrestrial and aquatic ecosystems by air-borne $\mathrm{N}$ deposition can be reduced by decreasing $\mathrm{N}$ emissions. A case study from the Vanajavesi catchment illustrates the consequences of climate change and assumptions on agricultural yields and prices on the future loads of $\mathrm{N}$ and P. Another case study examines the relative erosion risk in the various subcatchments in the area, and a third case study deals with $\mathrm{N}$ deposition to habitats in the Natura 2000 conservation areas in the study area. 
The VEMALA model provides an estimate of external loading, outflow loading, retention and concentration of nutrients in all Finnish lakes (about 58,000 ), as well as nutrient loading source apportionment into main sources (agriculture, forests and forestry, scattered settlements and point sources) (Huttunen et al. 2014). In a previous version of VEMALA (version 1) nutrient leaching simulation is based on concentration-runoff relationship and an estimate of the annual loading from each field according to the VIHMA tool (Puustinen et al. 2010). VEMALA has been developed towards a more process-based nutrient loading model, by developing a catchment scale, semi-process-based model of total nitrogen (TN) loading, VEMALA-N, and by incorporating and developing a field scale process-based model, ICECREAM (Jaakkola et al. 2012), for total phosphorus (TP) loading simulations (version 2). VEMALA uses input data on meteorology (daily air temperature and precipitation), hydrology (daily discharge and water levels), water quality, agricultural field data (soil texture, slope, crop type), point loads (annual). There are six crop classes considered: spring cereals, winter cereals, grassland, root crops, green fallow and forest. The nitrogen processes included in the soil model simulating nitrate leaching are mineralization, nitrification, denitrification, immobilization, plant uptake, fertilizer input and dissolution of fertilizer. Agricultural TP loading is simulated in detail for each field depending on soil texture, slope and crop. Nutrient mass balance in the lakes is simulated by estimating external loading, outflow loading, sedimentation, internal loading (for phosphorus) and denitrification (for nitrogen). External loading, outflow loading and sedimentation all depend on the water balance calculated for each lake. The water balance model simulates inflow discharge, outflow discharge, lake volume and also residence time. Sedimentation rate is lake specific and calibrated based on the lake concentration observations and related to the residence time and the mean TP concentration in the lake. VEMALA was run with three scenarios, (a) climate change with present agricultural practices, (b) climate change and optimistic assumptions on agricultural yield and prices, (c) and climate change but less optimistic assumptions on agricultural yields.

The climate scenarios used in the simulations with VEMALA were based on the mean climate change scenario from 19 Global Climate Models with the A1B mean emission scenario (IPCC 2000, 2007), which is the intermediate $\mathrm{CO}_{2}$ emission scenario. Two sets of assumptions on adaptation and prices were formulated, and land use and agricultural production were simulated using the DREMFIA dynamic agricultural sector model for Finland (Lehtonen 2004), resulting in two scenarios on agricultural yield and prices. The optimistic scenario assumes that yields of all crops increase by $30 \%$ until 2050 . Also crop prices increase in the optimistic scenario by $30 \%$ from 2010 to 2020 level, while meat prices increase by $15 \%$ and milk product prices by $7.5 \%$, due to rapidly increasing global demand. In the less optimistic scenario the yields of all crops increase linearly by $10 \%$ up to 2050 (appr. $0.25 \%$ per year). In this scenario agricultural commodity prices do not change, compared to 2010-2020. According to DREMFIA sector model simulations, farmland areas under cereals expand significantly, even 20-30 \% in the optimistic scenarios (with no set aside area), while pessimistic scenarios imply larger set aside, decreasing production and production intensity. In the optimistic scenarios grassland areas decrease since yields increase while the demand for grass forage is limited and grass is not a tradable product. However cereals exports (already existing 1995-2013) increase even considerably while dairy and meat exports are less responsive to market prices yields. This is because the role of national agricultural support payments for livestock is likely to remain significant, though gradually decreasing in the optimistic scenarios. The budgetary limits of national and EU support payments do not encourage to any significant increase in livestock production, while area subsidies mostly decoupled from production allow some production expansion.

A widely used indicator for estimating long term soil erosion is the Universal Soil Loss Equation (USLE), which is based on information on land use, soil type and topography (Wischmeier and Smith 1965, 1978). We have used a modification of USLE (Räsänen 2010) to calculate the relative erosion sensitivity for each of the ten subcatchments of the Vanajavesi water system. The relative erosion sensitivity is calculated as a product of four constant factors, determined by soil type, slope, land use and distance to water. In the modified version spatial differences in climate are not considered, and the ranges of the factors have been adjusted for Finnish 
conditions. For each river basin, the average and standard variation values were calculated from the individual $25 \mathrm{~m}$ pixel values.

Critical loads are a key method for assessing the efficiency of air pollution prevention measures within both the LRTAP convention under the United Nations Economic Commission for Europe as well as within the EU National Emission Ceilings Directive (Bull et al. 2001; Hettelingh et al. 2013). We determined the exceedance of empirical critical loads of nitrogen $\left(C L N_{e m p}\right)$ for the Natura 2000 habitats in the pilot area. Values of $C L N_{\text {emp }}\left(\mathrm{mg} \mathrm{Nm}^{-2}\right)$ have been estimated on the basis of the response of vegetation to $\mathrm{N}$ deposition (Bobbink et al. 2010) for groups of natural and seminatural ecosystems that have been classified according to the European Nature Information System (EUNIS). Receptor-specific estimates of the total (dry and wet) deposition of nitrogen $\left(\mathrm{NO}_{2}, \mathrm{NH}_{3}\right)$ were obtained as output of the EMEP model (Simpson et al. 2012) for a grid of $0.5^{\circ}$ longitude and $0.25^{\circ}$ latitude. For each grid cell, the total area of each habitat type was determined. The deposition to forest was used for woodland habitats, deposition to semi-natural vegetation for mire, fen and bog habitats, while grid average deposition was used for the other habitats, e.g. lakes. Exceedances of $C L N_{e m p}\left(\mathrm{mg} \mathrm{Nm}^{-2}\right)$ were calculated as the positive difference between the receptorspecific total deposition of $\mathrm{N}$ and $C L N_{\text {emp }}$. For each grid cell and for all Natura 2000 sites in the pilot area, the average exceedances were calculated as habitatspecific area-weighted averages $\left(A A E C L N_{\text {emp }}\right.$, $\mathrm{mg} \mathrm{Nm}^{-2}$ ).

The deposition scenarios used in the evaluation of the exceedance of critical loads of eutrophication consisted of estimates of the total (dry and wet) deposition of nitrogen $\left(\mathrm{NO}_{2}, \mathrm{NH}_{3}\right)$. They were obtained as output of the EMEP model (Simpson et al. 2012) for the years 2005, 2010, 2030 and 2030 for a grid of $0.5^{\circ}$ longitude and $0.25^{\circ}$ latitude. The scenarios represent air pollutant emissions consistent with the revised Gothenburg protocol and current legislation (Amann et al. 2011).

\section{Study area for pilot application}

The study area Vanajavesi basin is located in the southern boreal taiga zone in south Finland, with large coniferous forests (Fig. 3). The bedrock is primarily granodiorite and gneiss with some granite, with dominantly moraine soils and some organic soils. Surface waters in the area are part of the Kokemäenjoki river basin, with ten subcatchments of the 2 nd level of
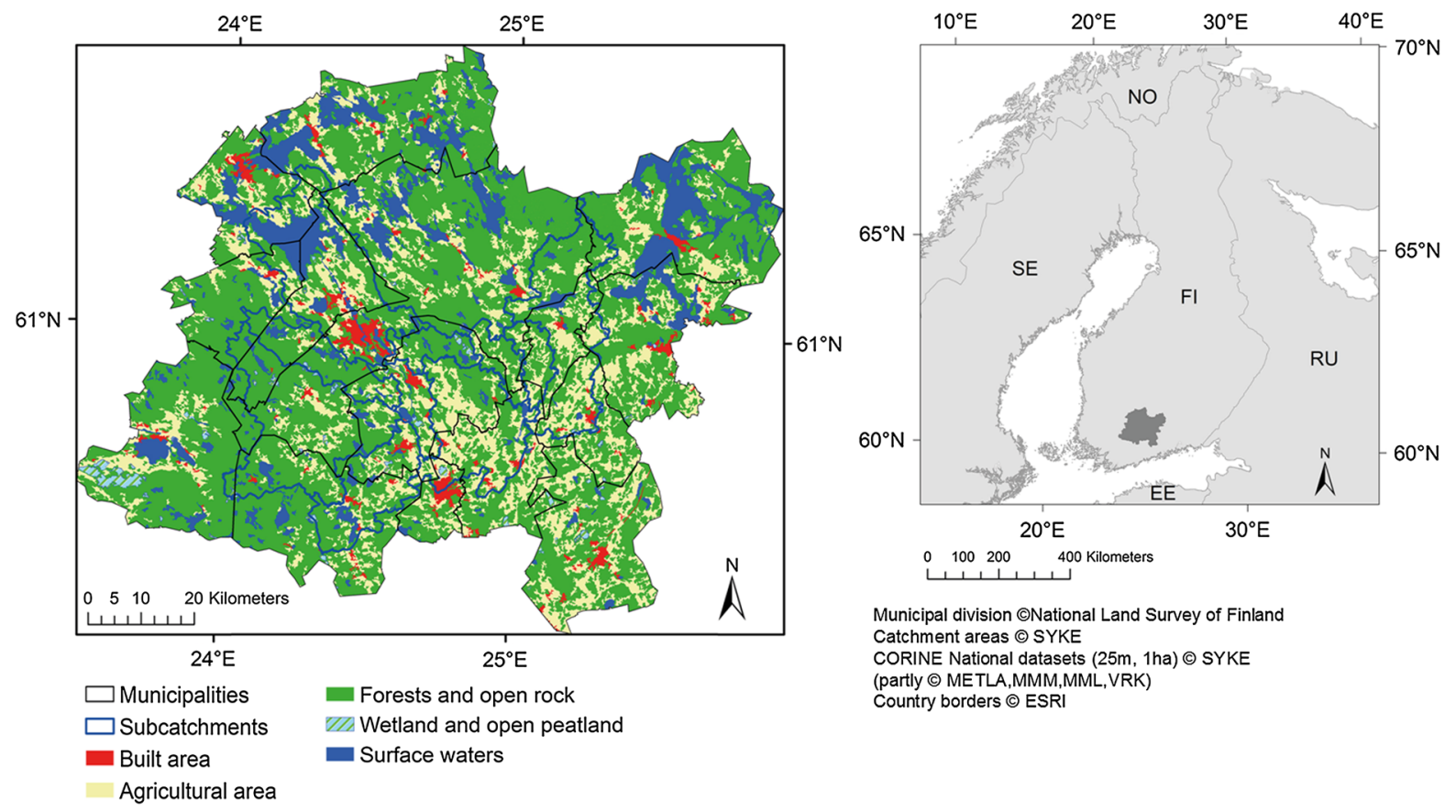

$0 \quad 100200 \quad 400$ Kilometers

Municipal division @National Land Survey of Finland

Catchment areas $\odot$ SYKE

CORINE National datasets $(25 \mathrm{~m}, 1$ ha) $\odot$ SYKE

(partly @ $\mathrm{ME}$ TLA,MMM,MML,VRK)

Country borders $\odot$ ESRI

Fig. 3 Land cover classes, municipalities and subcatchments of the Vanajavesi water system, South Finland 
the Finnish watershed division (Appendix 1 Table 2). The whole catchment area of Lake Vanajanselkä is $2,700 \mathrm{~km}^{2}$ and that of Lake Pääjärvi $220 \mathrm{~km}^{2}$. The surface area of Lake Vanajanselkä is $103 \mathrm{~km}^{2}$ and Lake Pääjärvi $13.4 \mathrm{~km}^{2}$. The lake percentage varies from one to $23 \%$. Lammi Long-term Ecological Research (LTER) area is located in the basin. There are 14 municipalities in the area, covering totally $8,400 \mathrm{~km}^{2}$, with a population density ranging from 9 to 233 persons per $\mathrm{km}^{2}$, the average density in 2013 being 28 persons per $\mathrm{km}^{2}$ (Appendix 1 Table 3 ). There are various Natura 2000 (Evans 2012) protected habitats in the area, altogether covering $348 \mathrm{~km}^{2}$ (Appendix Table 4), including coniferous, as well as mixed deciduous and coniferous woodland, raised and blanket bogs, as well as mires bogs and fens, and oligotrophic as well as dystrophic lakes. Although the conservation areas of this region do not appear in the highest national priority class in the Zonation-based ranking (Lehtomäki and Moilanen 2013) reported by Mikkonen and Moilanen (2013), they represent a large variety of habitats locally important for biodiversity conservation. Bird observation data and laser scanning data are available for part of the basin (Fig. 4) (Vihervaara et al. this issue).

\section{Results}

Biodiversity

Structural indicators for 14 forest parameters and the preferences of 41 bird species on those measures were mapped and analysed in the pilot study area. For example, the comparison of distributions of observed and randomly generated data showed that for high biomass classes, the proportion of pixels surrounding the bird observations was higher than that of the randomly generated data. Forest biomass could thus be identified as an indicator of biodiversity, while also other important aspects affecting the biodiversity such as high proportion of deciduous trees were mapped spatially explicitly (Vihervaara et al. this issue).

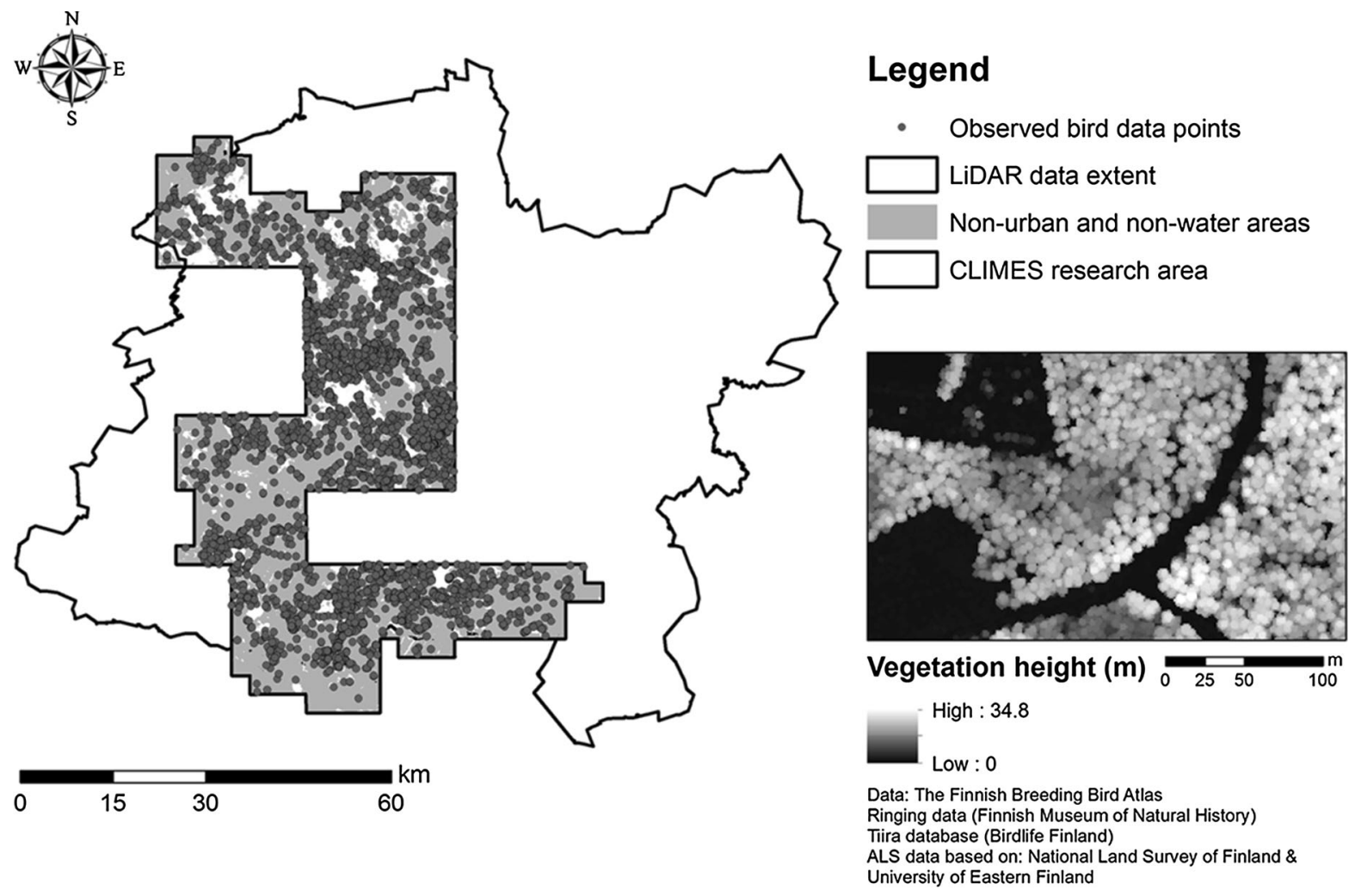

Fig. 4 Spatial distribution of bird data observations in the CLIMES research area in the Vanajavesi region 
Climate change mitigation

The first climate change mitigation case study showed that the forests were the largest $\mathrm{C}$ sink in the Vanajavesi region in 2009. Aggregated over the 14 municipalities the entire study area was a carbon sink. The annual sink in the area of 14 municipalities was $650 \mathrm{kt} \mathrm{CO}_{2}$ eq which corresponds to $78 \mathrm{tCO}_{2}$ eq km $\mathrm{km}^{-2}$ and $2.8 \mathrm{t} \mathrm{CO}_{2}$ eq per capita. Croplands, peat extraction sites, water bodies and undrained mires are all emission sources whereas forests are a large carbon sink turning the land use related GHG budget negative resulting to $\mathrm{C}$ sequestration into the ecosystem (Fig. 5). The aggregated anthropogenic emissions of the area was $2,100 \mathrm{kt} \mathrm{CO}_{2}$ eq which corresponds to $250 \mathrm{t} \mathrm{CO}_{2}$ eq km $\mathrm{km}^{-2}$ and $9.2 \mathrm{t} \mathrm{CO}_{2}$ eq per capita. Calculated for each municipality separately, the land use related GHG budgets varied considerably from 80 to $-300 \mathrm{kt}$ of $\mathrm{CO}_{2}$ eq. For most municipalities the budgets remained negative indicating a net carbon sink.

The case study related to using harvest residues for bioenergy showed that the negative effect of decreasing the $\mathrm{C}$ sink by removing the residues continued, although smaller, throughout the calculated period up to 2040. The estimated carbon sink of forests was equal to $390 \mathrm{kt} \mathrm{CO}_{2}$ year $^{-1}$ in Hämeenlinna in 2010 if no harvest residues were removed from the forests for

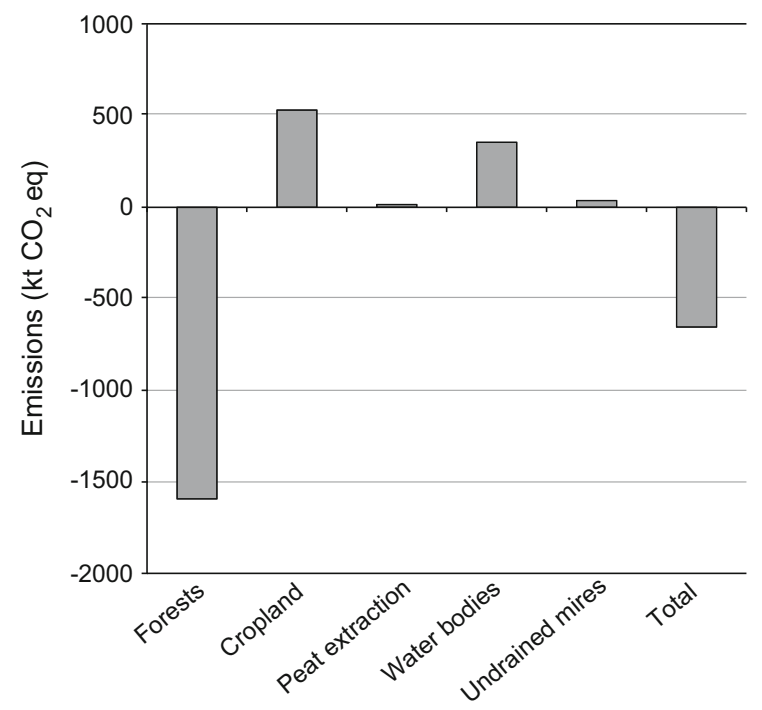

Fig. 5 Present net emissions of greenhouse gases $\left(\mathrm{kt} \mathrm{CO}_{2}\right.$ eq) for various land use classes (year 2009), totals for all 14 municipalities in the Vanajavesi region bioenergy production. Tree biomass represented $58 \%$ of this sink and soil $42 \%$. Harvest residues available in the forests were enough to produce about $340 \mathrm{GWh}$ of district heating each year of our scenario. This was $63 \%$ of the total consumption in 2010 . The residues reduced the emissions of district heating production by $63 \%$ or $128 \mathrm{kt} \mathrm{CO}_{2}$ year $^{-1}$ compared to producing this energy from coal (Fig. 7). Removing the residues from forests weakened the carbon sink by $118 \mathrm{kt} \mathrm{CO}$ year $^{-1}$. As a difference between these two effects, the net emissions were reduced by $10 \mathrm{kt} \mathrm{CO}_{2}$ year ${ }^{-1}$. When the use of the harvest residues was continued, the effect on the carbon sink became smaller year after year (Fig. 6). The sink was reduced by $61 \mathrm{kt} \mathrm{CO}_{2}$ year $^{-1}$ in 2020 and by $35 \mathrm{kt} \mathrm{CO}_{2}$ year $^{-1}$ in 2040. The effect on the emissions remained the same. Thus, the net emissions were reduced by $64 \mathrm{kt} \mathrm{CO}_{2}$ year $^{-1}$ in 2020 and by $90 \mathrm{kt} \mathrm{CO}_{2}$ year $^{-1}$ in 2040.

\section{Eutrophication mitigation}

The first eutrophication case study showed that only the optimistic scenario (2) with moderate fertilizer input would decrease the TN loading. According to the optimistic agricultural yield and price scenario grassland areas decrease because of higher grass yields but relatively stable livestock production. The higher meat and milk prices of the markets are still not lucrative enough for Finnish livestock farming to expand. Cereal areas expand, however, and the cereals output increase about twofold. In the less optimistic scenario,

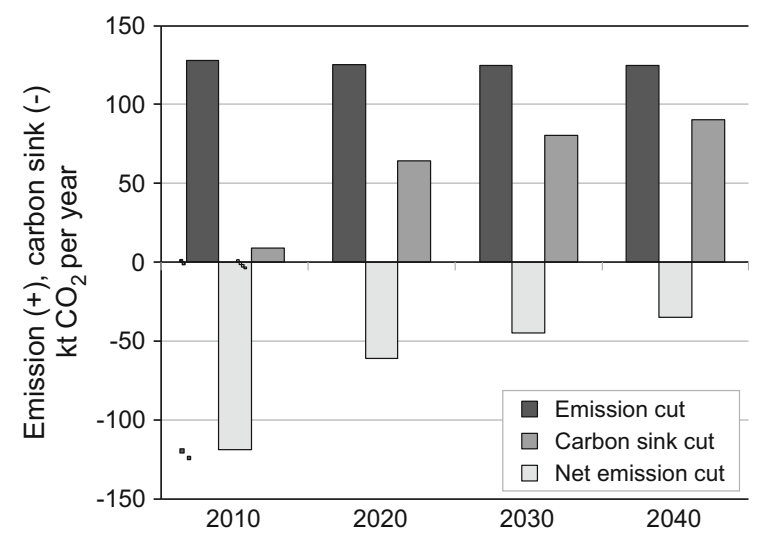

Fig. 6 Present and future cuts in emission, sink and net emission ( $\mathrm{kt} \mathrm{CO}_{2}$ per year) due to the use of harvest residues in the production of district heating in Hämeenlinna municipality 

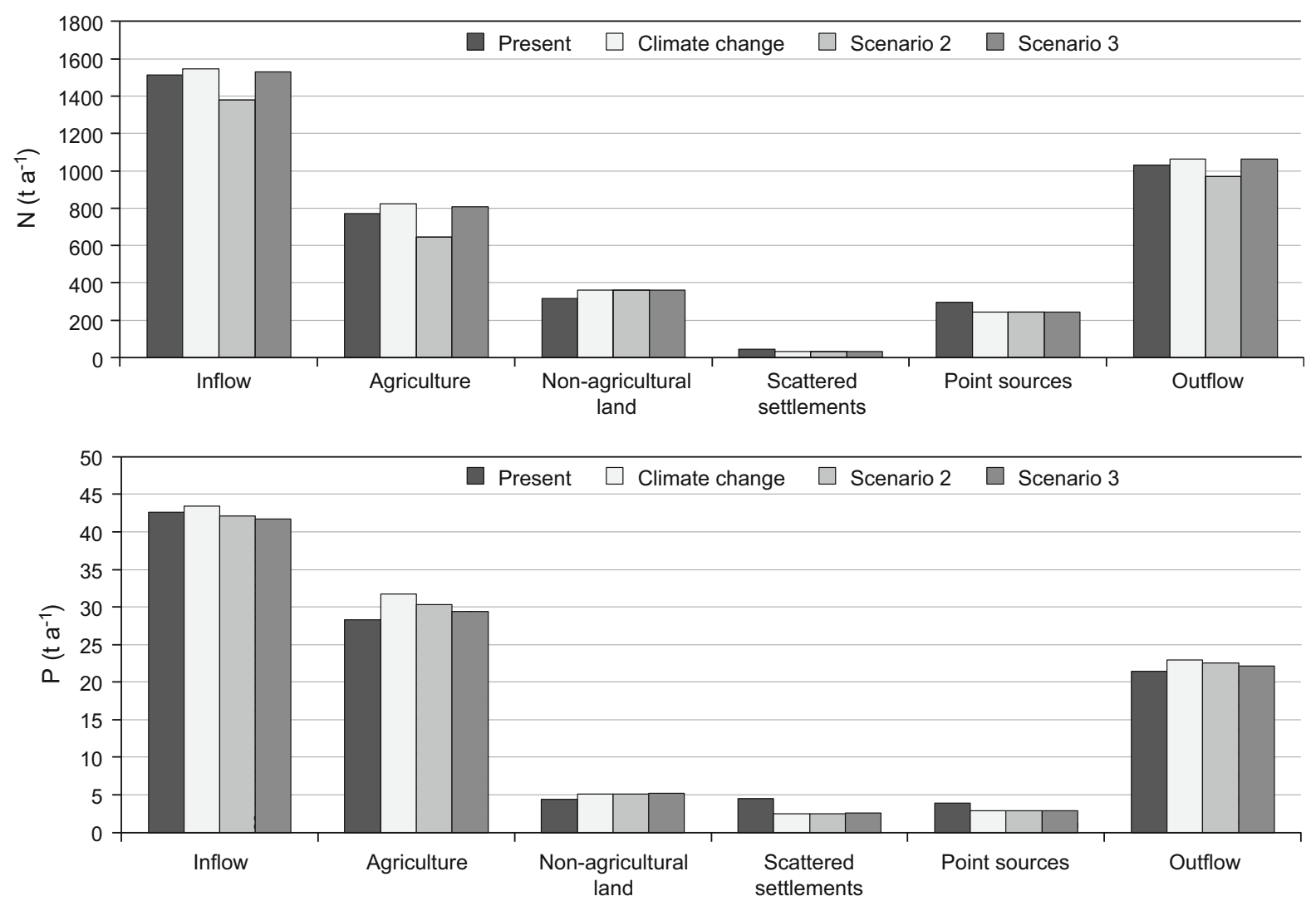

Fig. 7 Present and future total $\mathrm{N}$ and $\mathrm{P}$ loading in Vanajavesi catchment in response to scenarios of climate change and assumptions on agricultural yield and prices. Scenario 2

$10 \%$ yield increase leads to an increase of about $20 \%$ in cereals production. Simulated present TN and TP loadings to Vanajavesi for the period 2001-2010 are in the ranges between 1,420 and 1,520 $\mathrm{t} \mathrm{year}^{-1}$, and

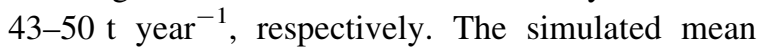
concentrations in the lake are TN $1.4 \mathrm{mg} \mathrm{L}^{-1}$ and TP $30 \mu \mathrm{g} \mathrm{L}^{-1}$. A large portion, $67 \%$ of TP loading, originates from agricultural areas, $10 \%$ from forested and bog areas, $11 \%$ from scattered settlement and $9 \%$ from point load sources. About half, $51 \%$ of TN loading stems from agricultural areas, while $21 \%$ comes from forested areas and bogs, $3 \%$ from scattered settlements and $20 \%$ from point load sources. The TN loading from agricultural and forested areas increases in the climate change scenario mainly due to the increase in runoff. Due to the declining trend in TN fertilizer use during the 2001-2010, the fertilizer amount used in the climate change scenario is lower compared to the average, and combines climate change with optimistic development of agricultural yields and prices and scenario 3 combines climate change with less optimistic assumptions on agricultural yields

TN leaching from agricultural areas is only $7 \%$. In the climate change scenario the TP load from agricultural areas and forested areas increase due to the increase in runoff. Decrease in loading from scattered settlement and point sources compensates diffuse TN and TP, and total TN and TP loading to Vanajavesi does not show considerable change (Fig. 7). In the combined climate change and agricultural change scenarios our results indicate that in the optimistic yield scenario (2) plant uptake is increasing and fertilizer increase is only moderate therefore nitrogen surplus in soils is decreasing, and $\mathrm{TN}$ leaching form agriculture is decreasing in scenario 2. In less optimistic yield scenario (3) increase of plant uptake, as well as fertilizer use is moderate, and therefore change in nitrogen balance in the soil is not so pronounced and the increase in TN loading is mainly caused by increase in runoff. In the combined climate and agricultural change scenarios TP load from 


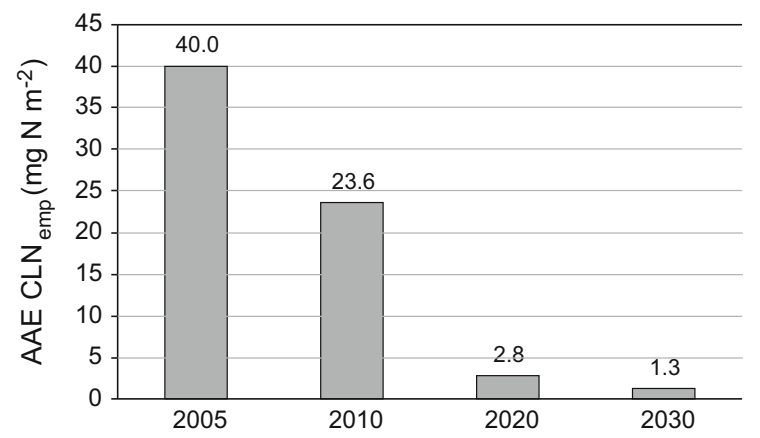

Fig. 8 Present and future area weighted average exceedance of empirical critical loads of $\mathrm{N}$ for Vanajavesi Natura 2000 sites $\left(\mathrm{mg} \mathrm{Nm}^{-2}\right.$ ) estimated with air pollutant emissions consistent with the revised Gothenburg protocol and current legislation

agricultural areas increases moderately, because $\mathrm{P}$ balance in soils decreases slightly due to the increased plant uptake in future climate and only moderate increase in fertilizer use.

The second eutrophication case study indicates that the differences in erosion sensitivity between the subcatchments of the Vanajavesi water system are small. The estimated relative erosion sensitivity differs only slightly between the individual basins (0.42-0.51), while the uncertainty of each estimate $(0.15-0.18)$ is larger than the difference between the basins.

The third eutrophication case study shows that continually decreasing $\mathrm{N}$ deposition is reflected as lower levels of excess $\mathrm{N}$ in the Natura 2000 conservation areas in the Vanajavesi region. The deposition of nitrogen to the study area has decreased since 2005 and is projected to continue to decrease as a result of current legislation on air pollution and the revised Gothenburg protocol. The lower $\mathrm{N}$ deposition is reflected in lower values of the exceedance of critical loads (Fig. 8). The AAECLN $N_{\text {emp }}$ values decrease from 40 to 3 and $1 \mathrm{mg} \mathrm{Nm}^{-2}$ from the year 2005 to 2020 and 2030, respectively.

\section{Discussion}

The advantage of the ESLab virtual research environment lies in providing a framework for integrating ES assessments at different spatial and temporal scales. The pilot version of ESLab is a first step in the generation of a virtual toolbox for the ES researchers.
We are continuing our work to define the technical system architecture of ESLab. This work includes describing the linkages between the input and output data sets and functions involved as well as detailed metadata descriptions of these. Defining the architecture also involves decisions concerning whether the input data and functions will be accessed via open data or run on stand-alone computers. The long term goal is to provide an open web tool, publishing its results on open interfaces. Future implementations of ESLAb will include a glossary and the options of including interactive features will be explored, with the aim of developing a shared language and facilitate on-going communication within the community of users from multiple disciplines (Pooley et al. 2014).

The next development phase of ESLab will consider including tools for trade-off analysis and future aims include extending the web processing environment to allow the usage of pre- or user defined models within ESLab. The results of the individual ES examples presented here all involve uncertainties that depend on the characteristics of the spatial data, the temporal drivers and the process rate parameters used to derive the results. Biodiversity indicators were based on airborne laser scanning data for forest structure, and on bird census data for species diversity. Some uncertainty in this method may be linked to the precision of the original bird observations (Vihervaara et al. this issue). The risk for eutrophication was estimated to decrease for Natura 2000 protected habitats in response to future $\mathrm{N}$ deposition scenarios. The uncertainties of the eutrophication risk are related to the estimates of the empirical critical loads, and to how the habitats were assigned the critical loads. The present risk of sediment loading was evaluated to be evenly distributed between the catchments of the study area. Any future changes in land use that would result in different risks of sediment loading were not analysed in the pilot application. The assignment of values to the erosion factors has a subjective component, which contributes to the uncertainty of the risk assessment. Furthermore, the USLE method does not account for all the differences in topography or land use between the subcatchments. Carbon budgets of natural ecosystems were assessed on the scale of land cover units and separately for each municipality. Aggregated over the 14 municipalities, the entire study area was a carbon sink in 2009. This pattern would be different for another year. The carbon sink of 
Hämeenlinna municipality was estimated to decrease with the use of forest harvest residue for bioenergy production. Here, there is some uncertainty related to the downscaling of the business-as-usual forest resource scenario from the regional to the municipal level. In the combined climate change and agricultural change scenarios TP load from agricultural areas increases moderately, and a decrease in TN leaching from agricultural areas is found for an optimistic yield scenario, while an increase in TN is found with a less optimistic yield scenario. There are some uncertainties in the VEMALA model results that are linked to the parametrisation of the leaching processes. We are working on including estimates of the uncertainties in the outputs of ESLab.

It has widely been accepted that ES should be taken into account in natural resource management decisions. Integrating biodiversity protection with the provision of ES is a key element for sustainable land use planning (Vihervaara et al. 2012). It is also evident that the impact of global change drivers provides a major challenge for the sustainable management of the key ES (Mooney et al. 2009; Forsius et al. 2013). As also the results of the present paper illustrate, new policies such as the increasing use of bioenergy can have complex and long-lasting effects (Aherne et al. 2012; Kraxner et al. 2013). Hence, there is an increasing need for innovative quantification methods and tools evaluating ES on different landscape scales and under varying land use forms (Vihervaara et al. 2012). The constantly increasing amount of online services for the environmental data and its processing provides substantial possibilities for the ES research. In environmental disciplines in general, the development of virtual services based on open data and model sharing standards is currently intense (Feng et al. 2011; Ames et al. 2012; Evangelidis et al. 2014). While the full potential of information produced by public organizations is far from being realized (EC 2011b), it seems evident that virtual research environments aiming at specific topics can be expected to accelerate the collaboration between researchers and eventually enhance the utilization of research results, even to promote democracy. We are investigating forms of collaboration with developers and providers of ES tools (e.g. (Jackson et al. 2013); (Kopperoinen et al. 2014), virtual research environments (e.g. Hardisty et al. (2013) and decision support systems (Rapeli 2014).
Quantitative information about synergies and tradeoffs between different ES is important for evaluating management strategies. Bradford and D'Amato (2012) developed a method for comparing overall benefit and trade-off between different management options. Lautenbach et al. (2013) analysed biophysical trade-offs among bioenergy crop production based on rape seed, food crop production, water quantity, and water quality in a catchment in Central Germany. Their results indicate that the same level of bioenergy crop production can be achieved at different costs with respect to the other objectives (Lautenbach et al. 2013). Porto et al. (2014) identified management strategies to minimize the trade-off between cost, fire risk and biodiversity objectives in cork oak forest landscapes with multiple landowners. Smith et al. (2013) identified trade-offs of ecosystem management in the UK and found that optimal management is difficult to implement, in part because soil, water and air quality regulation are governed by different legislation. They also noted that the biggest conflict at a policy level may be caused by the fact that all regulating services, even if they are synergistic, may trade off against other ecosystem services. They conclude that "an ecosystem services framework may improve the regulation of climate, and soil, water and air quality, even in the absence of economic valuation of the individual services" (Smith et al. 2013). The management of agriculture, forestry, water quality and biodiversity is regulated by different national and international legislation and conventions. A complicated setting of institutional mechanisms (Primmer et al. 2013) influences the implementation of any one policy. Lack of ecological knowledge may hamper compliance with regulations (Similä et al. 2014). We believe that quantifying the impact of primary scenarios on key ES can aid in increasing ecological knowledge and in clarifying the consequences of different policies. For the applications demonstrated in the pilot we used sector-specific scenarios as opposed to broad scenarios based on integrated assumption concerning the main driving forces. In the next phase we will explore the possibilities to modify the sector-specific scenarios, where relevant, to include integrated assumptions on forestry, agriculture, climate and deposition. Our future development tasks include extending ESLab towards quantifying synergies and trade-offs between ecosystem services. 
Acknowledgments We thank Bojie Fu and two anonymous reviewers for valuable comments. The work was supported by the Academy of Finland by the projects "CLIMES Impacts of climate change on multiple ecosystem services: Processes and adaptation options at landscape scales" (MH, AA, KB, LM; Decision number 256231), LifeWatch (Decision number 271628) and MARISPLAN Marine spatial Planning in a changing climate (IH, VS; Decision number 140871; HL Decision number 140840). The work was also supported by the External Cooperation Program of the Chinese Academy of Sciences (GJHZ1215). Funding support was also received from the European Commission through the 7th Framework Programme projects ExpeER (SA; Grant agreement no. 262060) and OpenNESS (LM; Grant agreement no. 308428) as well as through the Life project MONIMET (MH, AA, KB; Grant agreement LIFE12 ENV/FIN/000409). We gratefully acknowledge the support of the funding agencies. We thank Inka Pippuri and Petteri Packalén, University of Eastern Finland, for calculating airborne laser scanning data, and Ari-Pekka Auvinen, Raimo Virkkala and bird watching organisations for preparation of bird data. We acknowledge the contribution of Maximilian Posch, Coordination Centre for Effects, RIVM, the Netherlands, in providing deposition values, and that of Ritva Koskinen in graphics support.

\section{References}

Aherne J, Posch M, Forsius M, Lehtonen A, Härkönen K (2012) Impacts of forest biomass removal on soil nutrient status under climate change: a catchment-based modelling study for Finland. Biogeochemistry 107(1-3):471-488

Amann M, Bertok I, Borken-Kleefeld J, Cofala J, Heyes C, Höglund-Isaksson L, Klimont Z, Nguyen B, Posch M, Rafaj P, Sandler R, Schöpp W, Wagner F, Winiwarter W (2011) Cost-effective control of air quality and greenhouse gases in Europe: modeling and policy applications. Environ Model Softw 26(12):1489-1501

Ames DP, Horsburgh JS, Cao Y, Kadlec J, Whiteaker T, Valentine D (2012) HydroDesktop: web services-based software for hydrologic data discovery, download, visualization, and analysis. Environ Model Softw 37:146-156

Bagstad KJ, Johnson GW, Voigt B, Villa F (2013a) Spatial dynamics of ecosystem service flows: a comprehensive approach to quantifying actual services. Ecosyst Serv 4:117-125

Bagstad KJ, Semmens DJ, Waage S, Winthrop R (2013b) A comparative assessment of decision-support tools for ecosystem services quantification and valuation. Ecosyst Serv 5:27-39

Barnosky AD, Hadly EA, Bascompte J, Berlow EL, Brown JH, Fortelius M, Getz WM, Harte J, Hastings A, Marquet PA, Martinez ND, Mooers A, Roopnarine P, Vermeij G, Williams JW, Gillespie R, Kitzes J, Marshall C, Matzke N, Mindell DP, Revilla E, Smith AB (2012) Approaching a state shift in Earth's biosphere. Nature 486(7401):52-58

Bentsen NS, Felby C (2012) Biomass for energy in the European Union: a review of bioenergy resource assessments. Biotechnol Biofuels 5(1):25
Bobbink R, Hicks K, Galloway J, Spranger T, Alkemade R, Ashmore M, Bustamante M, Cinderby S, Davidson E, Dentener F, Emmett B, Erisman JW, Fenn M, Gilliam F, Nordin A, Pardo L, De Vries W (2010) Global assessment of nitrogen deposition effects on terrestrial plant diversity: a synthesis. Ecol Appl 20(1):30-59

Böttcher H, Freibauer A, Obersteiner M, Schulze E-D (2008) Uncertainty analysis of climate change mitigation options in the forestry sector using a generic carbon budget model. Ecol Model 213(1):45-62

Böttcher H, Verkerk PJ, Gusti M, Havlik P, Grassi G (2012) Projection of the future $\mathrm{EU}$ forest $\mathrm{CO}_{2}$ sink as affected by recent bioenergy policies using two advanced forest management models. Glob Chang Biol Bioenergy 4(6):773-783

Bradford JB, D'Amato AW (2012) Recognizing trade-offs in multi-objective land management. Front Ecol Environ 10(4):210-216

Bull KR, Achermann B, Bashkin V, Chrast R, Fenech G, Forsius M, Gregor HD, Guardans R, Haubmann T, Hayes F, Hettelingh JP, Johannessen T, Krzyzanowski M, Kucera V, Kvaeven B, Lorenz M, Lundin L, Mills G, Posch M, Skjelkvåle BL, Ulstein MJ (2001) Coordinated effects monitoring and modelling for developing and supporting international air pollution control agreements. Water Air Soil Pollut 130(1-4):119-130

Butchart SHM, Walpole M, Collen B, van Strien A, Scharlemann JPW, Almond REA, Baillie JEM, Bomhard B, Brown C, Bruno J, Carpenter KE, Carr GM, Chanson J, Chenery AM, Csirke J, Davidson NC, Dentener F, Foster M, Galli A, Galloway JN, Genovesi P, Gregory RD, Hockings M, Kapos V, Lamarque J-F, Leverington F, Loh J, McGeoch MA, McRae L, Minasyan A, Morcillo MH, Oldfield TEE, Pauly D, Quader S, Revenga C, Sauer JR, Skolnik B, Spear D, Stanwell-Smith D, Stuart SN, Symes A, Tierney M, Tyrrell TD, Vié J-C, Watson R (2010) Global biodiversity: indicators of recent declines. Science 328(5982):1164-1168

Cardinale BJ, Duffy JE, Gonzalez A, Hooper DU, Perrings C, Venail P, Narwani A, Mace GM, Tilman D, Wardle DA, Kinzig AP, Daily GC, Loreau M, Grace JB, Larigauderie A, Srivastava DS, Naeem S (2012) Biodiversity loss and its impact on humanity. Nature 486(7401):59-67

CBD (2010) Convention on biological diversity. Strategic plan for biodiversity 2011-2020, including aichi biodiversity targets. Available from http://www.cbd.int/sp/. Accessed April 2014

Chapin III FS, Zavaleta ES, Eviner VT, Naylor RL, Vitousek PM, Reynolds HL, Hooper DU, Lavorel S, Sala OE, Hobbie SE, Mack MC, Diaz S (2000) Consequences of changing biodiversity. Nature 405(6783):234-242

Crossman ND, Bryan BA, de Groot RS, Lin Y-P, Minang PA (2013) Land science contributions to ecosystem services. Curr Opin Environ Sustain 5(5):509-514

Dick J, Maes J, Smith RI, Paracchini ML, Zulian G (2014) Cross-scale analysis of ecosystem services identified and assessed at local and European level. Ecol Indic 38:20-30

Dirnböck T, Grandin U, Bernhardt-Römermann M, Beudert B, Canullo R, Forsius M, Grabner M-T, Holmberg M, Kleemola S, Lundin L, Mirtl M, Neumann M, Pompei E, Salemaa M, Starlinger F, Staszewski T, Uziębło AK (2014) 
Forest floor vegetation response to nitrogen deposition in Europe. Glob Chang Biol 20(2):429-440

EC (1992) Council Directive 92/43/EEC of 21 May 1992 on the conservation of natural habitats and of wild fauna and flora. Available from http://ec.europa.eu/environment/nature/ legislation/habitatsdirective/ Accessed April 2014

EC (2000) Directive 2000/60/EC of the European Parliament and of the Council of 23 October 2000 establishing a framework for Community action in the field of water policy. Available from http://ec.europa.eu/environment/ water/water-framework/index_en.html Accessed April 2014

EC (2011a) Our life insurance, our natural capital: an EU biodiversity strategy to 2020. Communication from the commission to the European parliament, the council, the economic and social committee and the committee of the regions. COM (2011) 244. Available from http://ec.europa. eu/environment/nature/biodiversity/comm2006/2020.htm Accessed April 2014

EC (2011b) Open data. An engine for innovation, growth and transparent governance. Communication from the Commission to the European Parliament, the Council, the European Economic and Social Committee and the Committee of the Regions. COM (2011) 882 final. Available from http://eur-lex.europa.eu/legal-content/EN/TXT/PDF/ ?uri=CELEX:52011DC0882\&rid=2 Accessed April 2014

Evangelidis K, Ntouros K, Makridis S, Papatheodorou C (2014) Geospatial services in the cloud. Comput Geosci 63:116-122

Evans D (2012) Building the European Union's Natura 2000 network. Nat Conserv 1:11-26

Feng M, Liu SG, Euliss NH, Young C, Mushet DM (2011) Prototyping an online wetland ecosystem services model using open model sharing standards. Environ Model Softw 26(4):458-468

Forsius M, Anttila S, Arvola L, Bergström I, Hakola H, Heikkinen HI, Helenius J, Hyvärinen M, Jylhä K, Karjalainen J, Keskinen T, Laine K, Nikinmaa E, Peltonen-Sainio P, Rankinen K, Reinikainen M, Setälä H, Vuorenmaa J (2013) Impacts and adaptation options of climate change on ecosystem services in Finland: a model based study. Curr Opin Environ Sustain 5(1):26-40

Fu B, Wang S, Su C, Forsius M (2013) Linking ecosystem processes and ecosystem services. Curr Opin Environ Sustain 5(1):4-10

Haaspuro T (2013) LUONNIKAS_-laskentatyökalu kunnille luontoperäisten kasvihuonekaasujen nielujen ja lähteiden arviointiin. In Finnish. Novia publikation och produktion, series A. Yrkeshögskolan Novia, Fabriksgatan 1, Vasa, Finland. ISBN: 978-952-5839-75-3. Available from http:// www.novia.fi/assets/filer/Publikationer/Serie-A-Artiklar/ LUONNIKAS-laskentatykalu-kunnille_2.2013.pdf Accessed April 2014

Hakala K, Hannukkala AO, Huusela-Veistola E, Jalli M, Peltonen-Sainio P (2011) Pests and diseases in a changing climate: a major challenge for Finnish crop production. Agric Food Sci 20(1):3-14

Hardisty A, Roberts D, Biodiversity Informatics C (2013) A decadal view of biodiversity informatics: challenges and priorities. BMC Ecol 13(1):16

Hettelingh JP, Posch M, Velders GJM, Ruyssenaars P, Adams M, de Leeuw F, Lükewille A, Maas R, Sliggers J, Slootweg
J (2013) Assessing interim objectives for acidification, eutrophication and ground-level ozone of the EU National Emission Ceilings Directive with 2001 and 2012 knowledge. Atmos Environ 75:129-140

Huttunen I, Huttunen M, Piirainen V, Korppoo M, Lepistö A, Räike A, Tattari S, Vehviläinen B (2014) National scale nutrient loading model for Finnish watersheds - VEMALA. Environ Model Assess (in review)

IPCC (2000) Emission scenarios. Cambridge University Press, Cambridge

IPCC (2007) Contribution of Working Groups I, II and III to the Fourth Assessment Report of the Intergovernmental Panel on Climate Change (IPCC), Geneva, Switzerland

Jaakkola E, Tattari S, Ekholm P, Pietola L, Posch M, Bärlund I (2012) Simulated effects of gypsum amendment on phosphorus losses from agricultural soils. Agric Food Sci 21(3):292-306

Jackson B, Pagella T, Sinclair F, Orellana, B, Henshaw A, Reynolds B, McIntyre N, Wheater H, Eycott A (2013) Polyscape: a GIS mapping framework providing efficient and spatially explicit landscape-scale valuation of multiple ecosystem services. Landscape Urban Plan 112:74-88

Jax K, Barton DN, Chan KMA, de Groot R, Doyle U, Eser U, Görg C, Gómez-Baggethun E, Griewald Y, Haber W, Haines-Young R, Heink U, Jahn T, Joosten H, Kerschbaumer L, Korn H, Luck GW, Matzdorf B, Muraca B, Neßhöver C, Norton B, Ott K, Potschin M, Rauschmayer F, von Haaren C, Wichmann S (2013) Ecosystem services and ethics. Ecol Econ 93:260-268

Jylhä K, Laapas M, Ruosteenoja K, Arvola L, Drebs A, Kersalo J, Saku S, Gregow H, Hannula H-R, Pirinen P (2014) Climate variability and trends in the Valkea-Kotinen region, southern Finland: comparisons between the past, current and projected climates. Boreal Environ Res 19(Suppl. A):4-30

Kolstad CD (2000) Environmental economics. Oxford University Press, New York

Kopperoinen L, Itkonen P, Niemelä J (2014) Using expert knowledge in combining green infrastructure and ecosystem services in land planning: an insight into a new placebased methodology. Landscape Ecol 29:1361-1375

Kraxner F, Nordström E-M, Havlík P, Gusti M, Mosnier A, Frank S, Valin H, Fritz S, Fuss S, Kindermann G, McCallum I, Khabarov N, Böttcher H, See L, Aoki K, Schmid E, Máthé L, Obersteiner M (2013) Global bioenergy scenarios - future forest development, land-use implications, and trade-offs. Biomass Bioenergy 57:86-96

Lautenbach S, Volk M, Strauch M, Whittaker G, Seppelt R (2013) Optimization-based trade-off analysis of biodiesel crop production for managing an agricultural catchment. Environ Model Softw 48:98-112

Lehtomäki J, Moilanen A (2013) Methods and workflow for spatial conservation prioritization using Zonation. Environ Model Softw 47:128-137

Lehtonen H (2004) Impact of de-coupling agricultural support on dairy investment and milk production volume in Finland. Acta Agric Scand, Sect C 1(1):46-62

Lehtonen H, Liu X, Purola T, Rötter R, Palosuo T (2014) Farm level dynamic economic modelling of crop rotation with adaptation practices. MACSUR Mid-term Scientific Conference. Sassari, Italy 
Liski J, Perruchoud D, Karjalainen T (2002) Increasing carbon stocks in the forest soils of western Europe. For Ecol Manag 169(1-2):159-175

Liski J, Lehtonen A, Palosuo T, Peltoniemi M, Eggers T, Muukkonen P, Mäkipää R (2006) Carbon accumulation in Finland's forests 1922-2004 - an estimate obtained by combination of forest inventory data with modelling of biomass, litter and soil. Ann For Sci 63(7):687-697

MA (2005) Millennium ecosystem assessment: living beyond our means-natural assets and human well-being. World Resources Institute, Washington DC, USA

Mace GM, Norris K, Fitter AH (2012) Biodiversity and ecosystem services: a multilayered relationship. Trends Ecol Evol 27(1):19-26

Maes J, Paracchini ML, Zulian G, Dunbar MB, Alkemade R (2012) Synergies and trade-offs between ecosystem service supply, biodiversity, and habitat conservation status in Europe. Biol Conserv 155:1-12

Mikkonen N, Moilanen A (2013) Identification of top priority areas and management landscapes from a national Natura 2000 network. Environ Sci Policy 27:11-20

Mooney H, Larigauderie A, Cesario M, Elmquist T, HoeghGuldberg O, Lavorel S, Mace GM, Palmer M, Scholes R, Yahara T (2009) Biodiversity, climate change, and ecosystem services. Curr Opin Environ Sustain 1(1):46-54

Ortiz CA, Liski J, Gärdenäs AI, Lehtonen A, Lundblad M, Stendahl J, Ågren GI, Karltun E (2013) Soil organic carbon stock changes in Swedish forest soils-a comparison of uncertainties and their sources through a national inventory and two simulation models. Ecol Model 251:221-231

Palosuo T, Liski J, Trofymow JA, Titus BD (2005) Litter decomposition affected by climate and litter qualitytesting the Yasso model with litterbag data from the Canadian intersite decomposition experiment. Ecol Model 189(1-2):183-198

Peltoniemi M, Mäkipää R, Liski J, Tamminen P (2004) Changes in soil carbon with stand age-an evaluation of a modelling method with empirical data. Glob Chang Biol 10(12): 2078-2091

Pereira HM, Ferrier S, Walters M, Geller GN, Jongman RHG, Scholes RJ, Bruford MW, Brummitt N, Butchart SHM, Cardoso AC, Coops NC, Dulloo E, Faith DP, Freyhof J, Gregory RD, Heip C, Höft R, Hurtt G, Jetz W, Karp DS, McGeoch MA, Obura D, Onoda Y, Pettorelli N, Reyers B, Sayre R, Scharlemann JPW, Stuart SN, Turak E, Walpole M, Wegmann M (2013) Essential biodiversity variables. Science 339(6117):277-278

Pooley SP, Mendelsohn JA, Milner-Gulland EJ (2014) Hunting down the chimera of multiple disciplinarity in conservation science. Conserv Biol 28(1):22-32

Porto M, Correia O, Beja P (2014) Optimization of landscape services under uncoordinated management by multiple landowners. PLoS ONE 9(1):e86001

Potschin M, Haines-Young R (2011) Ecosystem services: exploring a geographical perspective. Prog Phys Geogr 35(5):575-594

Potschin M, Haines-Young R (2013) Landscapes, sustainability and the place-based analysis of ecosystem services. Landscape Ecol 28(6):1053-1065

Primmer E, Paloniemi R, Similä J, Barton DN (2013) Evolution in Finland's forest biodiversity conservation payments and the institutional constraints on establishing new policy. Soc Nat Res 26(10):1137-1154

Puustinen M, Turtola E, Kukkonen M, Koskiaho J, Linjama J, Niinioja R, Tattari S (2010) VIHMA-A tool for allocation of measures to control erosion and nutrient loading from Finnish agricultural catchments. Agric Ecosyst Environ 138(3-4):306-317

Rapeli L (2014) Natural resource economy. Governance by GeoDesign. In: Aronia Research Groups 2013. Forskningsoch utvecklingsinstitutet Aronia. AB Yrkeshögskolan vid Åbo Akademi. Available from http://www.novia.fi/assets/ Aronia/report-of-activities/Aronia-Research-2013.pdf Accessed April 2014

Räsänen A (2010) Kiintoaineen ja kasviravinteiden vesistökuormituksen riskialuekartoitus Aurajoen valumaalueella. (In Finnish). Jyväskylä University

Redford KH, Adams WM (2009) Payment for ecosystem services and the challenge of saving nature. Conserv Biol 23(4):785-787

Repo A, Böttcher H, Kindermann G, Liski J (2014) Sustainability of forest bioenergy in Europe: land-use-related carbon dioxide emissions of forest harvest residues. GCB Bioenergy:n/a-n/a

Ridder B (2008) Questioning the ecosystem services argument for biodiversity conservation. Biodivers Conserv 17(4):781-790

Rötter RP, Höhn J, Trnka M, Fronzek S, Carter TR, Kahiluoto H (2013) Modelling shifts in agroclimate and crop cultivar response under climate change. Ecol Evol 3(12):4197-4214

Ruoho-Airola T, Hatakka T, Kyllönen K, Makkonen U, Porvari $P$ (2014) Temporal trends in the bulk deposition and atmospheric concentration of acidifying compounds and trace elements in the Finnish Integrated Monitoring catchment Valkea-Kotinen during 1988-2011. Boreal Environ Res 19(Suppl. A):31-46

Similä J, Pölönen I, Fredrikson J, Primmer E, Horne P (2014) Biodiversity protection in private forests: an analysis of compliance. J Environ Law 26(1):83-103

Simpson D, Benedictow A, Berge H, Bergström R, Emberson LD, Fagerli H, Flechard CR, Hayman GD, Gauss M, Jonson JE, Jenkin ME, Nyíri A, Richter C, Semeena VS, Tsyro S, Tuovinen JP, Valdebenito Á, Wind P (2012) The EMEP MSC-W chemical transport model - technical description. Atmos Chem Phys 12(16):7825-7865

Smith P, Ashmore MR, Black HIJ, Burgess PJ, Evans CD, Quine TA, Thomson AM, Hicks K, Orr HG (2013) REVIEW: the role of ecosystems and their management in regulating climate, and soil, water and air quality. J Appl Ecol 50(4): 812-829

Statistics Finland (2013) Greenhouse gas emissions in Finland 1990-2011. National Inventory Report under the UNFCCC and the Kyoto Protocol. Available from http://unfccc.int/ files/national_reports/annex_i_ghg_inventories/national_ inventories_submissions/application/zip/fin-2011-nir-15apr. zip Accessed April 2014

Tietäväinen H, Tuomenvirta H, Venäläinen A (2010) Annual and seasonal mean temperatures in Finland during the last 160 years based on gridded temperature data. Int J Climatol 30(15):2247-2256

Tuomi M, Rasinmäki J, Repo A, Vanhala P, Liski J (2011) Soil carbon model Yasso07 graphical user interface. Environ Model Softw 26(11):1358-1362 
Vihervaara P, Rönka M, Walls M (2010) Trends in ecosystem service research: early steps and current drivers. Ambio 39(4):314-324

Vihervaara P, Kumpula T, Ruokolainen A, Tanskanen A, Burkhard B (2012) The use of detailed biotope data for linking biodiversity with ecosystem services in Finland. Int J Biodivers Sci, Ecosyst Serv Manag 8(1-2):169-185

Vihervaara P, Mononen L, Auvinen A-P, Virkkala R, Lü Y-H, Pippuri I, Packalén P, Valbuena R, Valkama J How to integrate remotely sensed data and biodiversity for ecosystem assessments at landscape scale. Landscape Ecol (this special issue)

Wischmeier WH, Smith DD (1965) Predicting rainfall-erosion losses from cropland east of the rocky mountains USDA

Wischmeier WH, Smith DD (1978) Predicting rainfall erosion losses: a guide to conservation planing USDA

Zanchi G, Pena N, Bird N (2012) Is woody bioenergy carbon neutral? A comparative assessment of emissions from consumption of woody bioenergy and fossil fuel. Glob Chang Biol Bioenergy 4(6):761-772 